UDK: 339:004.738.5

POSLOVNA EKONOMIJA BUSINESS ECONOMICS

Godina X

Originalni naučni rad

Broj II

Str 106-117

doi 10.5937/poseko10-12322

PhD Darjan Karabašević, , Assistant Professor ${ }^{1}$

University Business Academy in Novi Sad,

Faculty of Applied Management, Finance and Economics

PhD Gordana Petrović, ${ }^{2}$

Elementary school "Živadinka Divac" Kragujevac

PhD Mlađan Maksimović, , Research Assistant ${ }^{3}$

John Naisbitt University Belgrade,

Faculty of Management Zaječar

\title{
THE IMPACT OF THE LEVELS OF EDUCATION ON THE PERCEPTION OF CORPORATE SOCIAL RESPONSIBILITY
}

\begin{abstract}
The concept of corporate social responsibility in the broadest sense means the ways in which companies communicate with their stakeholders. The aim is to establish a balance between the economic, social and environmental aspects of the environment. In recent years, corporate social responsibility in Serbia is becoming more and more interesting. Serbia is, as a country, still in the process of transition with economic and social problems that further have an impact on the lack of responsible behavior by companies. As companies have an impact on social development in the communities in which they operate, they therefore also have responsibility that extends beyond the boundaries of making a profit. An important feature of our society is the responsibility of ranking on a scale of values of successful and modern companies. The aim of the study was to examine the effect of educational level
\end{abstract}

\footnotetext{
${ }^{1}$ darjankarabasevic@gmail.com

2 milicakg98@yahoo.com

3 mladjan.maksimovic@fmz.edu.rs
} 
on the perception of the concept of corporate social responsibility. The research was carried out on the territory of Šumadija district. Respondents' answers were analyzed by applying the method analysis of variance (ANOVA).

Key words: Corporate social responsibility; CSR dimensions; society; education.

\section{INTRODUCTION}

Corporate social responsibility (CSR) is a contemporary concept of running the company through which the company finds a balance between generating profits and ways to repay to the community in which it operates works and creates profit. Therefore, the aim of the corporate responsibility is to contribute to the long-term stability of the business, whilst simultaneously improve its relations with all stakeholders.

Karabasevic et al. (2016) state that in today's business environment, the competitiveness of companies is not only reflected for their business results and the position that some company occupy on the market, but is also reflected by company's characteristics in terms of wellbeing and responsibility towards community, support for the employees and business partners, care for the environment and sustainable development.

As far back as 1960, Davis (1960) has proposed definition for the term "socially responsible", i.e. that the "social responsibility refers to a businesses and represent decisions and actions taken for reasons at least partially beyond the firm's direct economic or technical interest". Commission of the European Communities (2002) defines CSR as a "concept in which companies integrates concern for society and the environment in its business activities and interaction with their stakeholders on a voluntary basis". Smith (2002) defines CSR as "an integration of business operations and values whereby the interests of all stakeholders, including customers, employees, investors, and the environment are reflected in the organization's policies and actions". According to Kotler and Lee (2004), CSR represents "commitment to improve community's wellbeing through discretionary business practices and contributions of corporate resources". Holme and Watts (2010) have defined that CSR is the "continuing commitment to business to behave ethically and contribute to economic development while improving the quality of life of the workforce and their families as well as of the local community and society at large". Corporate Social Responsibility (CSR) is a concept in which companies integrate into their business interactions with all stakeholders and social 
challenges related to the environment, on a voluntary basis (Atanacković, 2011).

It is notable that there are many other definitions besides the mentioned, however, what is common for all is that all take into account social and environmental impact of corporate activity.

In further analysis of the definitions of CSR, we can see that CSR as a concept is based on three key pillars, i.e. dimensions. The social dimension of CSR, which provides support to society and the local community, the economic dimension of CSR, which implies that the companies through CSR projects improve the positive image which ultimately affects the profitability and CSR dimensions of the natural environment which implies that the company's operations are carried out in a sustainable way respecting the environment (Dahlsrud, 2006; Waldman et al., 2006; Uddin et al., 2008; RobecoSAM AG, 2014; Åkerman, 2016). Graves et al. (2002), CSR dimensions indicated as "3Ps", i.e. P for Profit (economic dimension), People (social dimension) and $\mathrm{P}$ for Planet (environmental dimension).

Lately, more and more is being discussed about the impact of the application of the concept of CSR on the company's economic performance. Godfrey (2004), Margolis et al. (2009) and Crifo et al. (2016) in their research, emphasize that companies by applying the concept of CSR achieve better economic performance, in a way that they will achieve a competitive advantage in attracting resources and the quality personnel.

Karabasevic et al. (2016) state that the CSR has become a very important parameter in the evaluation of companies. Low score in the area of CSR can negatively affect the image of the company, which ultimately reflects to business results. For this reason, companies tend to apply the concept of CSR to nurture a positive image, which make it clear that the company takes care of all aspects of CSR, which is reflected in the care of employees, partners, the community and the natural environment. It follows that CSR becomes an important element in the sustainable operations of the company.

Kotler and Lee (2008) point out that CSR contributes to the increase of the competitiveness of enterprises because it leads to an increase in sales and market share, strengthens the position of brands, strengthens corporate image and the influence and strengthens the company's ability to attract and retain the most talented workforce. Rahim et al. (2011) state that companies believe, to a certain level, that their involvement in projects of corporate social responsibility has an impact on consumers' preferences. Their research confirmed that CSR components have significant connection with consumers' buying behavior. Undoubtedly, companies are aware of the fact that CSR, to a large extent, affects their business operations. So, corporations also now believe that, to a certain extent, the degree of their involvement in corporate 
social responsibility (CSR) does have certain effect on consumers' buying behavior.

In recent years, CSR in Serbia is becoming a subject of interest of various organizations, associations, and companies. The transition process and all the stronger presence of foreign companies on the Serbian market are stimulating factors in this process.

CSR in Serbia certainly is not at the level of developed economies, and the main reason is delayed transition. Serbian first activities in terms of CSR are starting with the operations of multinational companies. Multinational companies adjust their business with all markets in which they operate, and which must be socially operated in accordance with the actions of its parent company and its management guidelines for sustainable development of corporate social responsibility (Karabasevic, 2014).

Given the importance of CSR for the organization, CSR is becoming an important element of the business environment and it has acquired status within management education and research (Pfeffer and Fong, 2004). Although there are no many studies on the impact of education level on the perception of concept of CSR, special efforts have been made by Sobczak et al. (2006) in their research of the impact of higher education on students' and young managers' perception of companies and CSR. The main result of their study is that there is the impact of the different types of academic institutions on the respondents' perception of companies and their attitude towards CSR concept. Taking into considereation current gap in the literature regarding the levels of education on the perception of CSR, the main aim of this manuscript is to examine relation of level of education to the perception of the CSR concept in Šmadija district.

Therefore, this manuscript is organized in this way: In Section 1, Introduction is presented, Section 2 presents Materials and methods of the research, and Section 3 presents Results of conducted research and discussion. Finally, Conclusion are given in Section 4.

\section{MATERIALS AND METHODS}

The aim of this study was to examine the attitudes of the population of Šumadija district (Arandjelovac, Batočina, Knić, Kragujevac, Lapovo, Rača and Topola) on issues of knowledge of the concept of corporate social responsibility. Therefore, the paper analyzes the impact of demographic factor (level of education) to the perception of the concept of corporate social responsibility. The survey was anonymous and was carried out on the territory of Šmadija district in the period from February to April 2016. As an instrument for research a questionnaire was applied, which was distributed to a 
total of 146 participants, and the response was received from 110 respondents, which represents $75.34 \%$.This level of response was expected which is confirmed by the results in the literature (Das et al., 2000; Molina, 2007). For gradation four step Likert scale is applied, while the qualitative data processing was performed by using statistical package SPSS 23.0. For significant questions the arithmetic mean, median, standard deviation and standard error are shown.

Table 1 shows the demographic data of respondents.

Table 1. - Demographic data of respondents

\begin{tabular}{|c|c|c|}
\hline Characteristic & & $\%$ \\
\hline \multirow{2}{*}{ Gender } & Male & $48 \%$ \\
& Female & $52 \%$ \\
\hline \multirow{3}{*}{ Age } & $18-25$ & $14 \%$ \\
& $26-35$ & $25 \%$ \\
& $36-50$ & $26 \%$ \\
& $51-60$ & $24 \%$ \\
Level of education & $>60$ & $11 \%$ \\
\hline & Primary school & $24 \%$ \\
& High School & $54 \%$ \\
Sample according to & College & $8 \%$ \\
municipalities & Faculty & $14 \%$ \\
& Arandjelovac & $16 \%$ \\
& Batočina & $5 \%$ \\
& Knić & $5 \%$ \\
& Kragujevac & $58 \%$ \\
& Lapovo & $3 \%$ \\
& Rača & $5 \%$ \\
& Topola & $8 \%$ \\
\hline
\end{tabular}

Source - the authors' calculations

From the statistical tests, ANOVA was applied. ANOVA (analysis of variance) is a statistical model that describes a group of statistical procedures. This model was developed by the British statistician Ronald Fisher. Analy sis of variance is a statistical method used to examine the effect of one or more independent variables on a dependent variable. The independent variables are the influencing factors that contain more levels (groups) and their effect reflects on the levels of the dependent variable.

\section{RESULTS}

When asking questions on CSR, the aim was to show how the educational profile of the population is informed and familiar with the aforementioned concept. This concept today has an important place in the consideration of long-term prospects of survival and progress of the company. 
Of the total number of respondents $65 \%$ is familiar with the term of corporate social responsibility, $30 \%$ are partially familiar while the term is not known to the $5 \%$ of respondents. The importance of understanding the concept of corporate social responsibility is reflected in the need that the stakeholders of society must be more organized and more intensely involved in the implementation of the principle of CSR in companies.

Table 2. - Descriptive processing of self-evaluation and analysis of variance ANOVA by level of education of respondents

\begin{tabular}{|c|c|c|}
\hline \multicolumn{2}{|c|}{ Level of education } & Do you know what it means corporate \\
\hline \multirow{5}{*}{ Primary school } & The number of respondents & 26 \\
\hline & The arithmetic mean & 2.34 \\
\hline & Median & 2.00 \\
\hline & Standard deviation & 0.95 \\
\hline & Standard error & 0.12 \\
\hline \multirow{5}{*}{ High School } & The number of respondents & 60 \\
\hline & The arithmetic mean & 1.93 \\
\hline & Median & 1.00 \\
\hline & Standard deviation & 0.95 \\
\hline & Standard error & 0.12 \\
\hline \multirow{5}{*}{ College } & The number of respondents & 9 \\
\hline & The arithmetic mean & 1.46 \\
\hline & Median & 1.00 \\
\hline & Standard deviation & 0.76 \\
\hline & Standard error & 0.15 \\
\hline \multirow{5}{*}{ Faculty } & The number of respondents & 15 \\
\hline & The arithmetic mean & 1.73 \\
\hline & Median & 1.00 \\
\hline & Standard deviation & 0.96 \\
\hline & Standard error & 0.25 \\
\hline \multirow{2}{*}{ ANOVA } & $\mathrm{F}$ & 0.94 \\
\hline & Significance & 0.43 \\
\hline
\end{tabular}

Source - the authors' calculations

Table 2 shows the level of the degree of knowledge of the concept of corporate social responsibility which clearly shows that the level of education increases the level of knowledge of these concepts (lower average value $=$ higher level of knowledge). Assuming that strategic development and competitiveness of the Šumadija district and the quality of services are most dependent on human resources, it is necessary to consider the importance of the educational structure and the necessary investment in improving the quality 
of education. This is achieved through the prism of its shape and structural elements. In doing so, informal educational concept should not be ignored.

If the examination includes more than two groups, whose arithmetic mean is necessary to compare, it is necessary to apply the analysis of variance ANOVA. In this study was tested the relationship between intergroup variability of variance and the variance of intra-variability. ANOVA is used in order to determine whether there were differences between several arithmetic means and whether these differences are statistically significant or accidental. Therefore, Table 3 shows the results of ANOVA test, i.e. attitudes of the local population with different educational levels according to the concept of corporate social responsibility.

Table 3. - ANOVA - The attitudes of the local population with different educational qualifications according to the statements below

\begin{tabular}{|c|c|c|c|c|c|c|c|c|c|c|}
\hline \multirow{2}{*}{ Question } & \multirow{2}{*}{$\begin{array}{c}\text { Educatio } \\
\mathbf{n}\end{array}$} & \multirow{2}{*}{$\mathbf{N}$} & \multirow{2}{*}{$\mathbf{A M}$} & \multirow{2}{*}{ Median } & \multirow{2}{*}{$\begin{array}{c}\text { Std. } \\
\text { Deviation }\end{array}$} & \multirow{2}{*}{$\begin{array}{l}\text { Std. } \\
\text { Error }\end{array}$} & \multirow{2}{*}{ Min } & \multirow{2}{*}{ Max } & \multicolumn{2}{|c|}{ ANOVA } \\
\hline & & & & & & & & & $\mathbf{F}$ & $\begin{array}{c}\text { Significanc } \\
\text { e }\end{array}$ \\
\hline \multirow{5}{*}{$\begin{array}{l}\text { According to } \\
\text { you, the } \\
\text { company is } \\
\text { socially } \\
\text { responsible if } \\
\text { it creates } \\
\text { positive } \\
\text { financial } \\
\text { results and } \\
\text { new value. }\end{array}$} & $\begin{array}{c}\text { Primary } \\
\text { school }\end{array}$ & 26 & 1.77 & 2.00 & 0.710 & 0.139 & \multirow{5}{*}{1} & \multirow{5}{*}{4} & \multirow{5}{*}{3.276} & \multirow{5}{*}{0.043} \\
\hline & $\begin{array}{c}\text { High } \\
\text { School } \\
\end{array}$ & 60 & 2.07 & 2.00 & 0.880 & 0.114 & & & & \\
\hline & College & 9 & 2.11 & 2.00 & 0.928 & 0.309 & & & & \\
\hline & Faculty & 15 & 2.47 & 2.00 & 0.743 & 0.192 & & & & \\
\hline & Total & 110 & 2.05 & 2.00 & 0.844 & 0.080 & & & & \\
\hline \multirow{5}{*}{$\begin{array}{l}\text { The company } \\
\text { is socially } \\
\text { responsible if } \\
\text { it takes into } \\
\text { account the } \\
\text { impact of } \\
\text { their } \\
\text { decisions on } \\
\text { society and } \\
\text { the } \\
\text { environment. }\end{array}$} & $\begin{array}{c}\text { Primary } \\
\text { school }\end{array}$ & 26 & 1.54 & 1.00 & 0.647 & 0.127 & \multirow{5}{*}{1} & \multirow{5}{*}{3} & \multirow{5}{*}{3.092} & \multirow{5}{*}{0.045} \\
\hline & $\begin{array}{c}\text { High } \\
\text { School }\end{array}$ & 60 & 1.42 & 1.00 & 0.619 & 0.080 & & & & \\
\hline & College & 9 & 1.78 & 1.00 & 0.972 & 0.324 & & & & \\
\hline & Faculty & 15 & 1.33 & 1.00 & 0.617 & 0.159 & & & & \\
\hline & Total & 110 & 1.46 & 1.00 & 0.659 & 0.063 & & & & \\
\hline \multirow{5}{*}{$\begin{array}{l}\text { Companies } \\
\text { on the } \\
\text { territory of } \\
\text { Sumadija } \\
\text { district } \\
\text { during the } \\
\text { process of } \\
\text { creating } \\
\text { products and } \\
\text { its release on } \\
\text { the market, } \\
\text { take into } \\
\text { account } \\
\text { environment } \\
\text { al protection. }\end{array}$} & $\begin{array}{c}\begin{array}{c}\text { Primary } \\
\text { school }\end{array} \\
\end{array}$ & 26 & 2.96 & 3.00 & 0.662 & 0.130 & \multirow[b]{5}{*}{1} & \multirow[b]{5}{*}{4} & \multirow[b]{5}{*}{0.034} & \multirow[b]{5}{*}{0.991} \\
\hline & $\begin{array}{c}\text { High } \\
\text { School }\end{array}$ & 60 & 2.93 & 3.00 & 0.660 & 0.085 & & & & \\
\hline & College & 9 & 3.00 & 3.00 & 0.000 & 0.000 & & & & \\
\hline & Faculty & 15 & 2.93 & 3.00 & 0.799 & 0.206 & & & & \\
\hline & Total & 110 & 2.95 & 3.00 & 0.647 & 0.062 & & & & \\
\hline \multirow{5}{*}{$\begin{array}{l}\text { Companies } \\
\text { on the } \\
\text { territory of } \\
\text { Šmadija } \\
\text { district } \\
\text { regularly } \\
\text { support local } \\
\text { activities and }\end{array}$} & $\begin{array}{c}\text { Primary } \\
\text { school }\end{array}$ & 26 & 2.92 & 3.00 & 0.744 & 0.146 & \multirow{5}{*}{1} & \multirow{5}{*}{4} & \multirow{5}{*}{0.191} & \multirow{5}{*}{0.901} \\
\hline & $\begin{array}{c}\text { High } \\
\text { School }\end{array}$ & 60 & 2.85 & 3.00 & 0.755 & 0.097 & & & & \\
\hline & College & 9 & 2.89 & 3.00 & 0.782 & 0.261 & & & & \\
\hline & Faculty & 15 & 3.46 & 3.00 & 0.535 & 0.138 & & & & \\
\hline & Total & 110 & 3.03 & 3.00 & 0.721 & 0.069 & & & & \\
\hline
\end{tabular}




\begin{tabular}{|l|c|c|c|c|c|c|c|c|}
\hline $\begin{array}{l}\text { projects (eg. } \\
\text { donations, } \\
\text { sponsorships } \\
\text { ). }\end{array}$ & & & & & & & \\
\hline
\end{tabular}

Source - the authors' calculations

\section{DISCUSSION}

As indicated, the study aims to investigate the current gap in the literature regarding the level of education and knowledge of the concept of corporate social responsibility. Analyzing the obtained results, general conclusion can be drawn that there is a quite a high level of impact of levels of education on the knowledge of concept of CSR.

The analysis of data on means of values of respondents' answers in relation to the level of education leads to the conclusion that the local population generally agrees with the above statements. The highest levels of agreement have expressed respondents to the statement: "The company is socially responsible if takes into account the impact of their decisions on society and the environment. "The mean value of responses to this statement is most evident among the respondents with higher education, and amounts 1.33. Other groups of respondents have rated this statement with slightly higher grade (lower level of agreement).

These results were confirmed by one factor analysis of variance and posthoc and Scheffe's test on the level of significance of the $\mathrm{p}<0.05(\mathrm{~F}=3.092$, $\mathrm{p}=0.045$ ). In this way, it is concluded that there are significant differences between respondents with different educational qualifications. 
The highest mean of value and a minimum agreeing with the statement have responses to the statement: „Companies on the territory of Sumadija district regularly support local activities and projects (eg. Donations, sponsorships). "For this statement the highest mean value of the responses is 3.46 and that among the respondents with higher education. Analysis of variance showed that the differences between respondents of different educational qualifications at the level of significance $\mathrm{p}<0.05$ are not statistically significant $(\mathrm{p}=0.901)$.

\section{CONCLUSIONS}

The concept of social responsibility appeared during the 60s of the last century. The concept of socially responsible business performance poses a challenge for a modern economy. The concept of CSR over the years has changed and evolved, but today in the business and academic community of defining concepts differ. CSR usually involves the willingness of companies to conduct business not only for their own good, but for the good of the whole society. The crisis of the global economy showed that the current concept of operations is unsustainable and that it is necessary to change the mode of operation and use of natural resources. Social community is becoming more interested in what kind of influence on society as a whole have a company in carrying out its activities. Socially responsible companies with own examples show that they take care about the employees, local community and environment. Social responsibility is an important element in the evaluation of companies on the capital markets. Socially responsible companies are usually considered to be those that provide a contribution to the whole community. Through a process of education to a higher level improves the knowledge of man and perfects its ability to contribute to the formation of human personality. The level of education has an important role in the creation and further transfer of knowledge on CSR. The aim of this study was to examine the attitudes of the population with different levels of education on the territory of Šmadija region on issues of knowledge of the concept of corporate social responsibility. Therefore, considering existing gap in the current literature, the purpose of this paper was to investigate the impact of levels of education on the perception of CSR concept. Further, analyzing the obtained results, it can be concluded that there is a quite a high level of impact of levels of education on the knowledge of concept of CSR. Also, results lead us to conclude that the higher level of education increases the level of awareness and understanding of the concepts of corporate social responsibility and its application on the territory of our country. 
It is expected that residents who have a higher level of education with the acquired knowledge and skills significantly affect the movement and development of society in socio-responsible community, so they have a very great responsibility in raising awareness and providing knowledge to build a sustainable present and future.

\section{REFERENCES}

1. Åkerman, O., Oreski, M., \& Magnusson, G., (2016) Does CSR matter?: A Quantitative Dissertation on CSR Dimensions Impact on Brand Associations, Linaeus University, Sweden.

2. Atanacković, U., (2011) Društveno odgovorno poslovanje kao savremeni koncept biznisa, Škola biznisa, Vol. 1, pp. 143-148.

3. Commission of the European Communities, (2002) Corporate Social Responsibility, Main Issue, Brussels.

4. Crifo, P., Diaye, M. A., \& Pekovic, S., (2016) CSR related management practices and firm performance: An empirical analysis of the quantityquality trade-off on French data, International Journal of Production Economics, Vol. 171, pp. 405-416.

5. Dahlsrud, A., (2006) How Corporate Social Responsibility is Defined: an Analysis of 37 Definitions, Corporate Social Responsibility and Environmental Management, Vol. 15, No. 1, pp. 1-13.

6. Das, A., Handfield, R., B., Calantone, R. J. \& Ghoch, S., (2000) A contingent view of quality management - the impact of international competition on quality, Decision Sciences, Vol. 31, pp. $649-690$.

7. Davis, K., (1960) Can business afford to ignore social responsibilities? California management review, Vol. 2, No. 3, pp. 70-76.

8. Godfrey, P. C., (2004) The relationship between corporate philanthropy and shareholder wealth: A risk management perspective, Academy of Management Review, Vol. 30, pp. 777-798.

9. Graves, S. B., Waddock, S.A., \& Kelly, J., (2002) 100 Best Corporate Citizens, Business Ethics, Vol. 11, No. 2, pp. 8-13.

10. Holme, L., \& Watts, R., (2000) Corporate Social responsibility: Making Good Business Sense, The World Business Council for Sustainable Development, January 2010.

11. Karabašević, D., (2014) Sustainability model of corporate governance and corporate social responsibility in Serbia, $4^{\text {th }}$ International Symposium on Natural Resources Management, Zaječar, Serbia, Book of proceedings, pp. 69-74.

12. Karabasevic, D., Paunkovic, J., \& Stanujkic, D., (2016) Ranking of companies according to the indicators of corporate social responsibility 
based on SWARA and ARAS methods, Serbian Journal of Management, Vol. 11, No. 1, pp. 43-53.

13. Kotler, P. \& Lee, N., (2007) Korporativna društvena odgovornost, Učiniti najviše za svoju kompaniju i izabrati društveni cilj, Najbolje prakse vodećih kompanija, Čigoja, Beograd.

14. Kotler, P., \& Lee, N., (2004) Corporate social responsibility: Doing the most good for your company and your cause, John Wiley \& Sons, Hoboken, NJ.

15. Margolis, J., Elfenbein, H., \& Walsh, J., (2009) Does it pay to be good? A meta-analysis and direction of research on the relationship between corporate social and financial performance, Harvard University Working Paper.

16. Molina, L. M., (2007) Relationship between quality management practices and knowledge transfer, Journal of Operations Management, Vol. 25, pp. 682-701.

17. Pfeffer, J., \& Fong, C. T. (2004) The business school 'business': Some lessons from the US experience. Journal of management studies, Vol. 41, No. 8, pp. 1501-1520.

18. Rahim, R. A., Jalaludin, F. W., \& Tajuddin, K., (2011) The importance of corporate social responsibility on consumer behaviour in Malaysia, Asian academy of management journal, Vol. 16, No. 1, pp. 119-139.

19. RobecoSAM AG, (2014) The sustainability Yearbook 2014. URL: http://www.pplus.nl/resources/articlefiles/SustainabilityYearbook2014.pdf (25.07.2016)

20. Smith, K., (2002) ISO considers corporate social responsibility standards, The Journal for Quality and Participation, Vol. 25, No. 3, p.42.

21. Sobczak, A., Debucquet, G., \& Havard, C. (2006). The impact of higher education on students' and young managers' perception of companies and CSR: an exploratory analysis. Corporate Governance: The international journal of business in society, Vol. 6, No. 4, pp. 463-474.

22. Uddin, M.B., Hassan, R.M. \& Tarique, K.M., (2008) Three Dimensional Aspects of Corporate Social Responsibility, Daffodil International University Journal of Business and Economics, Vol. 3, No. 1, pp. 199-212.

23. Waldman, D.A., Siegel, D.S., \& Javidan, M., (2006) Components of CEO Transformational Leadership and Corporate Social Responsibility, Journal of Management Studies, Vol. 43, No. 8, pp. 1703-1725. 


\section{APPENDIX 1. QUESTIONNAIRE ON KNOWLEDGE OF CSR CONCEPT}

Demographic group of questions:

Q1. Gender of respondents;

Q2. Place of residence;

Q3. Level of education;

Q4. Age structure;

Q5. Working status;

CSR group of questions:

Q1. According to you, the company is socially responsible if it creates positive financial results and new value?

Q2. The company is socially responsible if it takes into account the impact of their decisions on society and the environment?

Q3. Companies on the territory of Šmadija district during the process of creating products and its release on the market, take into account environmental protection?

Q4. Companies on the territory of Šumadija district regularly support local activities and projects (eg. donations, sponsorships)?

Q5. The company where I work is corporate socially responsible?

Q6. Obstacles in previous activities related to corporate social responsibility are tough financial situations in companies?

Q7. The bad economic situation adversely affects the development of Šumadija District?

Ovaj rad je primljen 11.06.2017., a na sastanku redakcije časopisa prihvćen za štampu 31.03.2017. godine. 